This item was submitted to Loughborough's Research Repository by the author.

Items in Figshare are protected by copyright, with all rights reserved, unless otherwise indicated.

\title{
Aeromobile elites: private business aviation and the global economy
}

PLEASE CITE THE PUBLISHED VERSION

http://dx.doi.org/10.4324/9780203078532

\section{PUBLISHER}

Taylor and Francis

\section{VERSION}

SMUR (Submitted Manuscript Under Review)

\section{PUBLISHER STATEMENT}

This work is made available according to the conditions of the Creative Commons Attribution-NonCommercialNoDerivatives 4.0 International (CC BY-NC-ND 4.0) licence. Full details of this licence are available at: https://creativecommons.org/licenses/by-nc-nd/4.0/

\section{LICENCE}

CC BY-NC-ND 4.0

\section{REPOSITORY RECORD}

Budd, Lucy C.S.. 2019. "Aeromobile Elites: Private Business Aviation and the Global Economy”. figshare. https://hdl.handle.net/2134/17605. 


\title{
Aeromobile elites: private business aviation and the global economy
}

\author{
Lucy Budd
}

Transport Studies Group

School of Civil and Building Engineering

Loughborough University

Leicestershire

LE11 3TU

UK

\begin{abstract}
There is no debate about whether flying privately is more productive. You control when, where and with whom you fly. You skip the check-ins, connections, baggage handling and delays that can make flying such a headache. And you replace those problems with more meetings, more time with clients and more sales (NetJets 2010).
\end{abstract}

\section{Introduction}

The opening vignette, taken from the website of one of the world's largest operators of business aircraft, NetJets, is unequivocal: business aviation saves time and enhances productivity by enabling users to avoid the stresses, delays, and congestion associated with conventional passenger air travel. For the sector's critics, however, particularly during times of economic downturn, it represents a profligate, highly inequitable, and environmentally unsustainable manifestation of capitalist production which enables a small number of cash-rich but time-poor politicians, corporate executives, Royalty, and celebrities to bypass the spatial and temporal constraints imposed by conventional airline schedules and fly around the world in comfort, at a time and in the company of their choosing, to destinations they desire to visit in an aeromobile vehicle that effectively insulates and isolates them from less affluent others.

Although business aviation only accounts for a small (albeit very high yield) segment of the global air transport market, its socio-cultural impacts are profound and the 'bizjet', in particular, has become a powerful cultural symbol of wealth, social-political status, and prestige. Indeed, in an era of unprecedented global aeromobility in which over two billion people board a commercial flight every year, how one flies has become an increasingly important social differentiator and indicator of relative power and status. While full-service airlines have conventionally offered multiple classes of travel to separate higher-yielding First and Business Class passengers from customers flying in Economy, these crude forms of aerial segregation still oblige 
passengers to travel in the company of strangers and depart from particular airports at times that suit the airline, not the individual. As a consequence of the strict social and spatial regimes imposed by commercial airlines, a distinct subcategory of commercial aviation practice emerged in the United States in the mid 1920s and rapidly spread around the world to serve the particular and often demanding mobility needs of society's most affluent members.

For a wealthy few, business aviation, along with other forms of elite surface and maritime mobility (on which see Atkinson and Flint 2004; Atkinson 2006; and Atkinson and Blandy 2009), enable users to bypass conventional forms of transport and timetabled spaces of flow and create personalised and bespoke geographies of movement. By facilitating the selective reconfiguration of global time-space and effectively cleaving the trajectories of the superrich away from those of the less affluent, business aviation creates and reproduces highly exclusionary spaces of corporeal mobility which present an exciting prospect for mobilities research. Yet while a number of studies have begun to investigate the oft-hidden mobilities and interior spaces of luxury trains, yachts, and cruise ships, comparatively little work has explored the unique spatialities and choreographies of private business or corporate aviation.

Taking its cue from the developing literature on the multiple socialities of passenger aviation (on which see Adey 2010; Adey et al 2007; Budd 2011; and Budd and Hubbard 2010), this chapter examines the bespoke aerial mobilities that are performed by the space-rich yet time-poor users of private business aircraft. More specifically, it analyses the motivations for, and users of, business aircraft and examines the role and the implications that the creation and maintenance of new 'affluent infrastructures' of aeromobility, including private jets and dedicated business aircraft registers, have had for the organisation and reproduction of global society.

\section{Structure of the chapter}

The chapter is divided into eight subsections. The first defines and then charts the development of private business aviation from the early 1920s to the present day. This is followed by an examination of the scale and scope of contemporary business aviation activities around the world. Sections three and four respectively provide an insight into who uses business aviation and how business aircraft are used while section five offers a critical consideration of the extent to which six key discourses of comfort, convenience, speed, productivity, status, and flexibility - collectively create a need for, and access to, exclusionary spaces of mobility that reinforce the social stratification of the superrich and create new geographies of connectivity and socio-economic interaction. The dedicated corporate aircraft register on the Isle of Man is offered, in section six, as an exemplar of how the global business aviation sector is becoming increasingly fragmented as the wealthiest business aviation users seek new ways to subtly differentiate themselves from other groups. The seventh 
section identities some of the contemporary challenges associated with conducting research into elite aeromobilities. The penultimate section discusses possible future trajectories of future of business aviation and the chapter concludes by discussing the extent to which contemporary forms of elite aeromobility may require current understandings of aerial travel to be reframed.

\section{Taking flight - the elite practices of business aviation}

The term 'business aviation' invariably conjures up images of sleek, streamlined jets, and connotations of wealth, opulence, and prestige. As a mobility genre, business aviation is habitually constructed as something that is desirable and which is routinely compared favourably with the perceived stresses, indignities, and delays associated with flying on scheduled commercial aircraft. The sector is also depicted as catering for the mobility needs of a small group of socially privileged individuals, including film, television, music, and sport celebrities, CEOs, and Royalty. According to the International Business Aviation Council (IBAC 2008) business aviation differs from commercial aviation because the former involves the operation or use of aircraft that are generally not available for public hire by companies or individuals 'for the carriage of passengers or goods as an aid to the conduct of their business'. As a consequence, Cwerner (2009: 226) suggests that business aviation 'provides strategic network capabilities to an increasing number of corporations and industries' and plays a 'growing role in shaping...the social relations that underpin the global economy'.

While the use of specialist aircraft for business purposes can be traced back to the early 1920s when major US corporations began using private aircraft to shuttle executives between company headquarters and manufacturing sites that were not linked by regular commercial services (Sheehan 2003), business aviation really emerged as a distinct subset of civil aviation practice from the late 1950s and early 1960s onwards when a new range of dedicate aircraft, including jets, began to be produced for the executive market (Bilstein 1984). Today, business aviation activities encompass a wide range of business models and operating characteristics, ranging from fixed-wing corporate flights in twin-seater turboprop aircraft, to 'VVIP' business jets and owner-operated helicopters. However, despite the apparent diversity, all these activities can be classified as belonging to one of three types, namely commercial, corporate, or owner-operated business aviation, according to the type of business model adopted.

The first, commercial business aviation, describes a situation in which a third party operator flies a business aircraft on behalf of a private client. These third party operators may offer ad-hoc (on demand) aircraft charter and/or air taxi services or operate fractional ownership schemes that allow corporations or individuals to purchase defined units of flight time on a particular aircraft in their fleet. Under these arrangements, the third-party operators supply everything that is needed for a flight, 
including aircraft, flight and cabin crew, fuel, insurance, maintenance, catering, and flight plans. These 'timeshares in the sky' allow companies or individuals to buy access to a private aircraft for a set number of hours per year at a fraction of the cost of purchasing the aircraft outright. The price of the service depends on the size of the aircraft and the number of flight hours that are required. Typically, customers buy a share in an aircraft in blocks of 25 hours (or multiples thereof) and pay monthly maintenance fee in addition to 'pay as you fly' fuel, catering, landing fees, and navigation charges. The high level of integration that these commercial operators achieve facilitate the rapid 'go now' creation of bespoke travel arrangements and aircraft can be in the air in as little as 10 hours notice, 24 hours a day, 365 days a year, to satisfy the mobility needs of the most demanding and discerning of clients. Such modes of operation are reportedly popular among small and medium-sized enterprises as well as individuals who want access to a private aircraft but not pay the purchase price and ongoing maintenance and crew costs associated with owing an aircraft outright.

The second principal type of operation, corporate business aviation, refers to a situation in which a company or an individual owns an aircraft outright and directly employs the personnel required to operate it. This regime enables the majority of flight operations to be performed 'in house' without the need for external providers (as described above). However, the high start up and ongoing management costs of this type of operation render it beyond the financial means of all but the largest and wealthiest of corporations or individuals. As its name implies, the final category, owner-operated business aviation, describes flights where an aircraft's owner also acts as its pilot.

In order to fulfil the operational needs of a diverse group of users and flight missions, a wide range of fixed and rotor wing aircraft have been developed for the business aviation market. These aircraft range in size and performance from single-seat propeller-powered aircraft, that can operate from very short runways, to executive helicopters, long range business jets, and 'VVIP' aircraft such as the Airbus 319 Corporate Jet, the Boeing Business Jet (which is based on a 737 aircraft) and executive Boeing 747s and Airbus A340s. However, the aircraft type that is arguably most synonymous with business aviation is the mid-range 6-10 seat 'bizjet'.

These sleek and aerodynamic aircraft were first developed in the late 1950s when jet engines were becoming the propulsion mode of choice for civilian aircraft. In 1957, the world's first executive jet took off on its maiden flight. Lockheed hoped that its new JetStar, which could cruise at 550 miles per hour at an altitude of 33,000ft, would generate considerable numbers of commercial sales but the purchase price of US $\$ 1.5$ million discouraged many potential buyers (Bilstein 1984). However, despite the JetStar's disappointing sales figures, American entrepreneur William Lear believed an untapped market for executive jets existed and he sought to develop his 
own aircraft. The performance of the resulting LearJet far exceeded that of the JetStar and an aggressive sales strategy combined with detailed attention to costs stimulated unprecedented demand for the new product. By the autumn of 1964, barely a year after the first flight, over 100 LearJets had been sold, and other US and foreign aircraft manufacturers began to design their own business jets to take advantage of the emerging market (Bushell 2000).

Today, there are well over a dozen major aerospace companies who manufacture business aircraft. Some, such as Cessna, Piper, and Beech, have been involved in executive aircraft manufacture since before the Second World War whereas others, including Embraer, Gulfstream, Grob, Boeing, and Bombardier entered the market more recently. Between them, they produce over 50 different types of business aircraft, from single engine light aircraft to long range business jets that cost tens of millions of US Dollars when new. Buyers are encouraged to configure their aircraft's exterior paintwork and interior fittings to their own exacting personal requirements to create a luxurious aerial 'home from home' or an office in the sky. However, the high acquisition and ongoing operating costs (which include, but are not limited to, crew salaries, fuel, maintenance, insurance, airport fees, and navigation charges) mean that bizjets, in particular, are a luxury obtainable only by a wealthy few. As a result, business jets have become the mobility tool of choice for the global superrich, political elites, and celebrities and their cultural cachet has endured. Indeed, access to a bizjet has become a major barometer of social status and thus personal and professional success.

\section{The scale and scope of global business aviation}

There are currently in excess of 31,000 dedicated business aircraft in operation around the world. This compares with around 17,500 commercial aircraft. Like its commercial counterpart, business aviation occurs on all seven continents but its geographic distribution is highly uneven. Unlike commercial aviation, however, business aviation was relatively unaffected by the global slump in passenger demand for air travel that followed the 9/11 terrorist attacks, record oil prices, and the recent economic downturn. Between 2001 and 2011, the world's business aviation fleet increased by almost 50\% from 21,459 to 31,166 units and growth was recorded every year except for 2007 (Figure 1). This contrasts sharply with the situation in the commercial sector where many airlines were declared bankrupt while others rationalised their route network, cut their workforce, and deferred aircraft deliveries in a desperate bid to remain operational. 
Figure 1: Growth of the world's business aircraft fleet, 2001-2011.

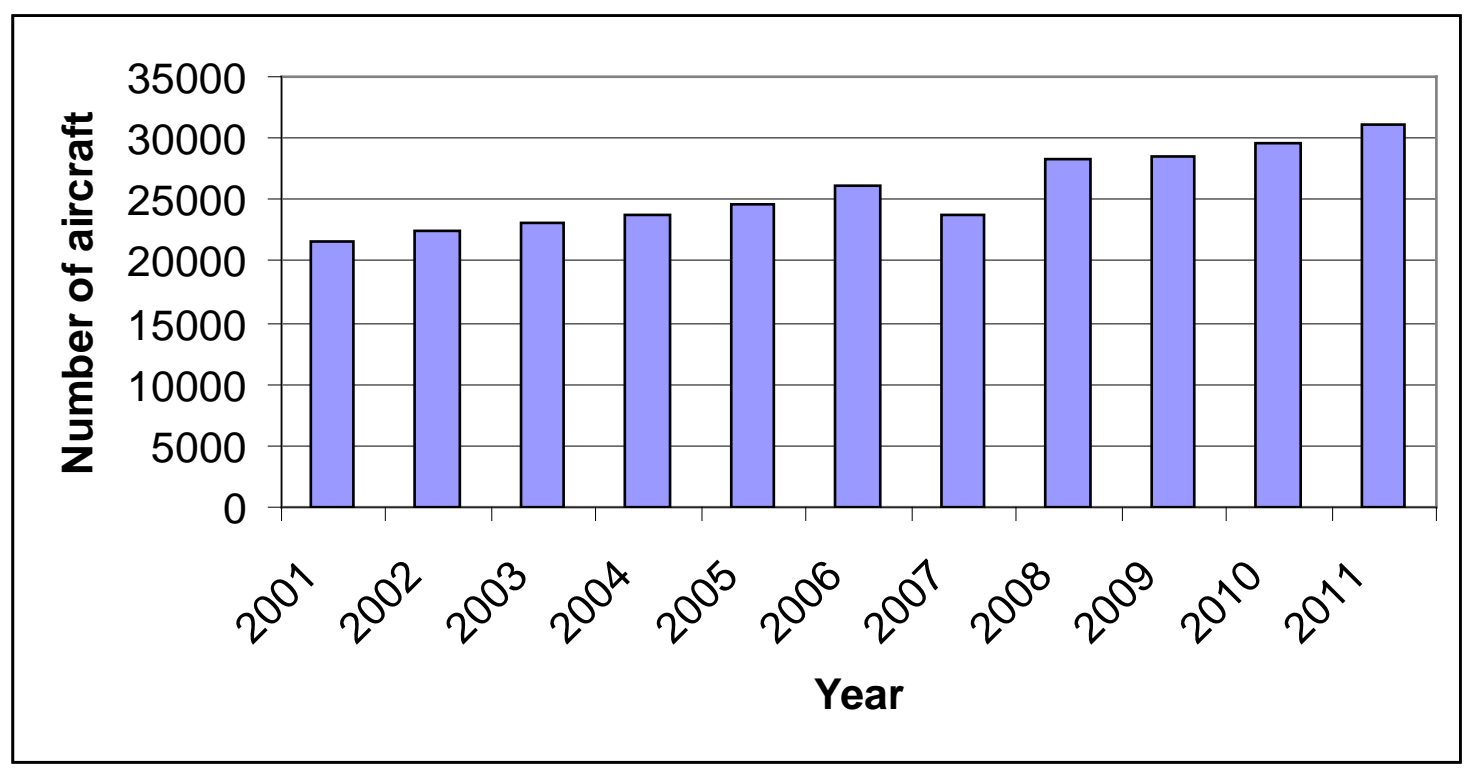

Source: derived from EBAA, 2012

Historically, business aircraft have been concentrated in a small number of the most economically developed countries in North America and western Europe but recent economic growth combined with structural and regulatory changes in other aviation markets has led to rapid growth elsewhere. In 2008, $72 \%$ of the world's business aircraft were registered in North America, with 10\% in Europe and only 6\% in South America (Budd and Graham 2009). By 2011, slowdown in US and Canadian markets combined with rapid growth in other world regions meant that North America only accounted for $45 \%$ of the world's business aircraft fleet while the proportions in Europe and South America had grown to 24\% and 20\% respectively (see Figure 2 overleaf). Particularly notable growth occurred in Brazil and Venezuela but despite economic growth in the Middle East, Pacific Rim, Asia, and Africa relatively few business aircraft are registered in these regions.

Although business aviation is an almost global phenomenon, the spatialities of business aircraft registrations are highly concentrated and uneven. Global aeronautical regulations stipulate that all civilian aircraft, irrespective of size or performance, are registered in a single country and display a unique alpha/numerical registration mark on the fuselage. All aircraft on the UK civil aviation registration, for example, have a registration mark that follows the format G-xxxx (where the xxxx are capital letters), while those on the Canadian register are similarly marked C-xxxx, and those on the German register D-xxxx. Civil aircraft registers can thus be used to determine where in the world business aircraft are registered. 
Figure 2: Distribution of business aircraft by world region, 2011.

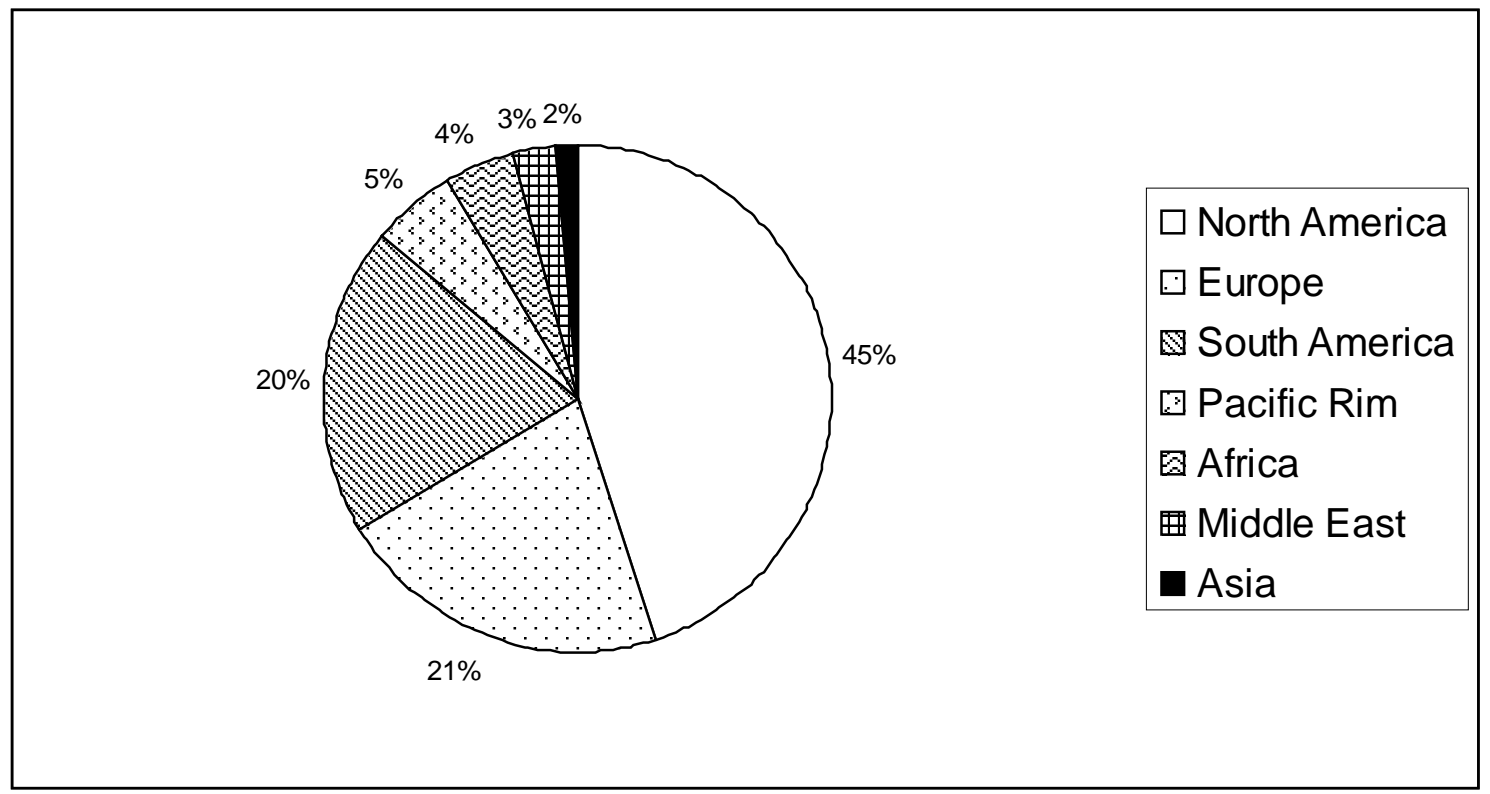

Source: derived from Flight Global (2011)

At the time of writing, only seven countries in the world have more than 500 business aircraft on their national aircraft registers and only four have more than 1,000. The country with by far the highest number of business aircraft registrations is the United States. In 2011, almost 18,000 business aircraft were registered in the US, nearly 15 times as many as second-placed Brazil and 27 times as many as Germany, the country with the higher number of business aircraft in Europe (Table 1). Interestingly, the top 10 countries for business aircraft registrations in 2008 were the same in 2011 although the position within the rankings had changed. With the exception of the USA, the business aircraft fleet in every country in the list grew between 2008 and 2011 despite the global economic downturn and recession in many key world markets (see Table 1). The fact that business aircraft registrations continued to grow during this period indicates that the business aviation sector was shielded from the effects of the downturn.

Table 1: Top 10 business aircraft fleets by country, 2011 (2008 figures in brackets).

\begin{tabular}{llll}
\hline Country & Number of aircraft & Country & Number of aircraft \\
\hline United States & $17,937(18,772)$ & UK & $639(316)$ \\
Brazil & $1,225(759)$ & Venezuela & $587(397)$ \\
Canada & $1,117(927)$ & Australia & $480(317)$ \\
Mexico & $1,035(887)$ & South Africa & $464(330)$ \\
Germany & $664(496)$ & France & $424(398)$ \\
\hline
\end{tabular}


While aircraft registrations provide a useful overview of the spatialities of global business aviation, they cannot offer any insights into where in the world the individual aircraft are used. Indeed for reasons of business expediency, political neutrality, or taxation, a business aircraft that is registered in Bermuda could be based in Europe while another registered in the USA could predominately be used on inter-island services in Australasia. Thus, in order to uncover where, how, and why business aircraft are used it is necessary to examine the type of people and organisations who are using them.

\section{The global high (net worth) flyers}

It is estimated that $60 \%$ of the world's business aircraft are owned by major multinational corporations, $20 \%$ by national Governments, $17 \%$ by small and medium-sized enterprises, and the remaining 3\% (or around 930 units) by wealthy individuals (PWc 2009). According to the US-based business aviation trade organisation the National Business Aviation Association (NBAA), business aircraft are 'productivity multipliers that allow passengers to conduct business en-route in complete privacy while reducing the stresses associated with travelling on commercial carriers' (NBAA 2004: 3). In 2001, a study of Fortune 500 companies reported that those that used business aircraft generated $146 \%$ more in cumulative returns than non-users and that CEOs believed business aircraft helped their company to identify and execute 'strategic opportunities' for new relationships, increase contact and visibility with clients, and develop new markets. Many of these advantages are the result of the inherent flexibility of business aviation. Having access to a private business aircraft immediately frees companies from the temporal constraints imposed by conventional airline schedules, react to emerging market opportunities and reach them before their competitors, and fly at a time that suits them. In addition, business aircraft enable companies to access airports which may be nearer to emerging opportunities but which commercial carriers do not serve.

In addition to enhanced temporal and spatial flexibility, the creation of on-demand and bespoke private aerial mobilities removes many of the stresses, congestion, and delays associated with major commercial airports, improves the safety and security of key personnel, and reduces opportunities for industrial espionage (Sheehan, 2003; IBAC 2008). It also makes employees feel valued and arguably helps a company or an individual project a positive and successful image. Passenger surveys have reported that employees feel that they are significantly more productive when they are flying on business aircraft than they would have been on conventional airlines (or even in their own office) and three times less likely to be resting or reading non-work related materials during the flight (NBAA 2004). According to the NBAA (2004: 19), these attributes collectively mean that 'business aircraft are good for the bottom line' as they enable users to 'consistently outperform non-operators in key economic performance measures, [including] annual sales volume, number of employees, value of assets, stockholders' equity and annual income'. 
While $77 \%$ of the world's business aircraft fleet are owned and operated by multinational corporations and small and medium-sized enterprises, the remainder are owned by a small group of very wealthy individuals. According to the 2010 World Wealth Report, the global population of High Net Worth Individuals (HNWIs), here defined as people with investible assets exceeding US\$1trillion, grew by $17.1 \%$ in 2009 to 10 million and their collective wealth increased by $18.9 \%$ to US\$39trillion (Capgemini and Merrill Lynch 2010). This growth was facilitated, in part, by GDP growth and policies of national fiscal stimulation that helped to reverse the effects of the 2008 global economic downturn, but also by the growing value of private corporations, particularly in Latin America and Asia-Pacific (ibid. 2010). As a consequence of their superior (and growing) purchasing power, HNWIs have historically invested in luxury consumer items including antiques, fine art and wine, racehorses, vintage cars, yachts, and aircraft (Beaverstock et al 2004). While the majority of these so-called 'passion collectables' are material statements of social status and accumulated wealth that enable their owners to engage in particular practices of leisure and consumption, personal aircraft enable the production of a specific jet setting lifestyle that is underpinned by unfettered access to rapid global mobility.

\section{Business Aviation: An entirely different type of flying?}

Clearly, the relative wealth of business aviation users vis-à-vis the general flying public means that the embodied practices and experiences of flying on a private aircraft differ quite considerably from those of passengers flying on conventional airlines. Indeed it is the very ability to socially and spatially segregate one's self from the stresses and unpleasantness of normal routines of flying that is one of the primary attractions of business aviation. Yet for all the apparent differences, a number of common refrains remain. Business aviation, like its commercial counterpart, transports people from where they are to where they want to be.

One of the primary uses of business aircraft is the transport of company employees. Typically, this will involve flying staff between offices and production sites, taking them to visit clients or enabling them to participate in trade shows, or ensuring that they arrive ahead of any competitor to secure new business when opportunities emerge. As later sections of this chapter will show, discourses of convenience, flexibility, and comfort have become instrumental in structuring how, when, and why business aircraft are used for this purpose. In addition to transporting company employees and executives, business aircraft may also be used to transport clients to and from meetings and reward high-performing employees. The possibility of flying on a private aircraft not only confers corporate status on the operator but may also act as a powerful incentive for employees to exceed sales targets or profit forecasts.

As well as moving people, business aircraft are also used for the carriage of samples, supplies, and documents. Usually, these constitute very high value, 
delicate, and often confidential or perishable products that have to be moved in accordance with strict deadlines under defined handling conditions and security protocols. Depending on the nature of the product, it may have to be transported in a protective container, packed into a strong cool box, and/or be accompanied by inhouse couriers or security personnel at all times along their journey. By using business aircraft to transport financially or intellectually valuable goods, companies ensure that they are in control of their supply chains and distribution channels at all times thus reducing the potential for delays, damage, or commercial espionage.

A further way in which business aircraft are used is for humanitarian and/or charity missions. Owing to their smaller size and ability to use less developed airfields, business aircraft can be used to take medical supplies and emergency aid to destinations that large conventional cargo aircraft cannot reach. They can also be mobilised relatively quickly and be the first to arrive at the scene of a natural disaster. Employing aircraft on such relief flights helps business aviation users to demonstrate their corporate social responsibility credentials. However, one of the most distinctive uses for business aircraft concerns direct applications or 'aerial services' such as aerial photography, atmospheric measurement, environmental monitoring, and aerial surveying. Here, the aircraft themselves are used as a platform for monitoring, advertising, crop spraying, or scientific experiments that could not be conducted in any other way. Many energy and infrastructure firms use helicopters and aircraft to survey electricity pylons, gas installations, and oil pipelines while national law enforcers and border control agencies may use them to police the integrity of borders and detect illegal activity. Consequently, as well as providing different ways of flying, business aircraft also arguably offer users a much more pleasant environment in which to fly.

\section{Business Aircraft: A better way to fly?}

By the late 1920s, business aviation had become an accepted, if not exactly widespread, feature of American commerce. For American aviation historian Roger Bilstein (1984), the growth in business aviation in the US in the late 1920s and early 1930 s can be attributed to increased industrialisation and the fact that many US lacked a regular scheduled air service. Consequently, many business executives discovered that private aircraft offered them tangible benefits of enhanced convenience, flexibility, speed, productivity, comfort, and status.

\section{Convenience}

For centuries, mobility has been a prized asset. Access to transportation, whether on horseback or, later, ship, road, rail, and air, enables people to travel to places outside their normal sphere of influence and take advantages of any personal, political, or commercial opportunities that may exist there. In the case of civil aviation, aircraft have enabled travellers to complete, in a matter of hours, journeys that would once have taken many days or weeks to accomplish by other modes. However, despite its 
advantages, conventional commercial air travel is rarely convenient. Passengers have to travel to the airport and fly at a time that suits the airline, not the individual, and in the company of strangers. In contrast, business aviation aims to make flying much more convenient by putting the user in charge of flight schedules and itineraries. "The company owned plane", opined an editorial in Factory and Management Magazine in 1928, "is almost indispensable" as it shortens travel time and increases "the range of action of executives" (cited in Bilstein 1984: 64) and this discourse of the convenience of private flying continues today.

In 2008, Grob aerospace ran a series of printed advertisements for their new business jet which claimed that the new $\mathrm{sp}^{\mathrm{n}}$ 'reaches places that others can't'. Interestingly, rather than draw attention to the aircraft's performance characteristics, the advertisement sought to emphasise the global reach of using their aircraft. Thanks to their smaller size, lower weight, and minimal ground handling requirements, business jets such as the $\mathrm{sp}^{\mathrm{n}}$ can access airports that commercial aircraft cannot serve. This enables users to access new markets and land at airports that are nearer to their clients, thereby saving time and reducing the need for lengthy ground transport connections to/from commercial airports. Studies of the business aviation sectors in Europe and the United States discovered that the scale, scope, and concentration of business aviation services within these two regions were very different from those of commercial services. Indeed, whereas the scheduled airline market is concentrated on a relatively small number of key routes and key airports, the business aviation market is more diffuse.

In Europe, the business aviation sector connects in excess of 100,000 airport pairs a year compared with the 30,000 airport pairs linked by scheduled airlines while in the US, business aviation serves ten times as many airports as all the commercial carriers combined (Marsh 2006; NBAA 2010). Thus, business aviation is not replicating the network of scheduled airlines but actively creating new links and patterns of aerial connectivity. Only $5 \%$ of all business aviation flights performed in Europe had a scheduled alternative (defined as having at least one scheduled flight every working day) while $64 \%$ of respondents to a 2010 study reported that they used business aircraft to support schedules that are not supported by conventional airlines, such as accessing multiple destinations within one working day (NBAA 2010). As a result, business aircraft are not only creating new aerial connections but also offering users the opportunity to perform new strategies of mobility.

In order to improve productivity and minimise ground time, most business aviation users choose to fly from smaller, less congested airports, that are as close to the intended destination as possible. In the case of London, this means flying into Farnborough, Northolt, or Biggin Hill as opposed to Heathrow or Gatwick and in Paris using Le Bourget in preference to Charles de Gaulle. These alternative airports are favoured by business aviation users and business aircraft operators because they 
are smaller and less congested, do not suffer from capacity constraints, offer a more attractive environment, and provide services that are specifically tailored to the needs of business aviation users (such as option of being driven out to the aircraft by your chauffeur and met again at the door of the aircraft on arrival).

\section{Flexibility}

In addition to exhibiting distinctive spatial patterns, business aviation also creates distinctive temporal patterns which arise from the inherent flexibility of the product. Access to a business aircraft, whether as a corporate or commercial user or as an owner-operator, enables the rapid creation of 'go now' flights that can be in the air within as little as 60 to 90 minutes of the service being requested. The ability to reach multiple destinations in the course of a single day and change itineraries in response to evolving situations are important drivers of business aviation growth. A 2001 study reported that access to such flexible regimes of aerial mobility improved organisational agility and enabled business aviation users to take advantage of new strategic opportunities, improved knowledge integration, and faster transaction speeds (Andersen 2001).

\section{Speed}

Paralleling the discourses of convenience and flexibility is that of speed. As early of mid 1920s, the advantages of the speed of business aircraft were being strongly advocated and potential users tempted with the idea that time saved equals money saved (Bilstein 1984). Clearly any advantages that are associated with being able to access a wide range of airports at convenient times would be negated if competitors arrived their first and 'sealed the deal' while you were still travelling. For that reason, business aircraft manufacturers developed a range of jet powered business aircraft that cruise at speeds that are comparable to (and in some cases exceed) those achieved by commercial aircraft. The Gulfstream G650, for example, can achieve a top speed of Mach .925 and is marketed as being the fastest civil aircraft in the sky (Gulfstream 2012). However, while much has been made of the 'need for speed' it could be argued that it is as much a cultural construct designed to sell aircraft as it is a commercial necessity. Certainly the contemporary marketing rhetoric that is used to sell business aircraft reinforces the idea that speed is good, powerful, and necessary and that the time that is saved by flying in a business aircraft is money well spent. 'Only the Citation X operates in that exclusive neighbourhood of Machcalibre speed. Only in a X are you the first to every opportunity...' (Cessna 2008). 'If time is money, then the time saved [by travelling in a business jet] is money in the bank (Gulfstream 2012).

\section{Productivity}

Part of the attraction of speed is that it allows people to cover greater distances in ever shorter periods of time. The Supersonic Concorde, which flew at twice the speed of sound and could cross the northern Atlantic Ocean in under three hours, 
was marketed as a 'time machine' that, thanks to the conventions of world timekeeping, allowed passengers to land in New York apparently before they had left London and therefore achieve more in a day. Business aviation operators similarly claim that the cumulative benefits of convenience, flexibility, and speed mean that people are more productive on business aircraft than they would have been on regular scheduled services or even in their own office.

Some of this improved productivity stems from the shorter turnaround times and reduced ground transport connections associated with business aviation, but the remainder is achieved during flight. An NBAA survey in 2010 reported that business aviation users spend $36 \%$ of a flight in productive meetings with company employees compared with just 3\% on commercial airlines (NBAA 2010). Employees were also found to be significantly more likely to spend their time on individual work-related tasks or in discussions with potential clients or customers (ibid. 2010). There is also anecdotal evidence that employees feel inspired (or perhaps compelled) to work harder and improve their productivity to justify the expense and privileges that their bosses have afforded to them (Andersen 2001).

\section{Comfort}

In addition to providing new opportunities for productive work and enabling the creation of bespoke mobilities, another important factor promoting the desirability of business aviation is the higher level of comfort it affords to its users. While the economic liberalisation of global aviation markets is often considered to be a socioeconomic success that has 'democratised' air travel and enabled more people to fly to more places more often, customer dissatisfaction is growing and, as Budd and Hubbard (2010) have shown, long queues, poor customer service, inadequate leg room, contradictory or confusing baggage restrictions, cancellations, delays, and boredom have become part of the lexicon of modern air travel. In comparison, business aviation operators claim that the stresses and unpleasantness that are often associated with commercial flying are almost absent when one flies on a business aircraft.

In recognition of the fact that many business aviation users use their aircraft as an extension of their boardroom, aircraft manufacturers have gone to considerable lengths to create 'offices in the sky' that are comfortable and thus conducive to productive work. The development of pressurised cabins mean that business jets can fly above the most turbulent weather and offer passengers a smoother ride. The cabin interior is often luxuriously appointed with sumptuous fabrics, furnishings, and fittings. Dedicated workspaces with ergonomically designed tables and seats are fitted as standard while other value-added customer preferences and amenities, including mood lighting, in-flight e-conferencing and telecommunications equipment, washrooms, galleys (stocked with luxury food and drink brands), and, in some of the larger aircraft, bedrooms, are provided. In order to lessen some of the undesirable 
physical sensations and bodily consequences of flight, the cabins of business aircraft are designed to be light and airy and are pressurised at relatively low altitudes to reduce the effects of fatigue and changes in atmospheric pressure.

\section{Status}

The sixth and final discourse of business aviation concerns that of status. There can be little argument that business aircraft, and bizjets in particular, are emblematic symbols of elite aeromobility. The aircraft, once purchased, are configured to reflect and expand the lifestyles of their users and are paraded as statements of wealth and social, political, or commercial status. Specialist publications such as 'Business Jet Interiors International' magazine publish items on luxury aerial living and advise bizjet owners on the latest range of aircraft cabin fragrances, coffee table books, tableware, hardwoods, fabrics, leathers, and interior design innovations to have entered the market. Already there is a considerable demand for 'value-added' customer preferences as owners and operators vie for the latest and most opulent interior fixtures and fittings that are designed by some of the world's leading luxury brands including Versace and BMW. In comparison with the opulence of the interior, the paint schemes that are applied to the exterior of the aircraft are often subtle and understated. It is rare for a company or an individual to paint their name or other recognisable symbol on the airframe. Indeed, anonymous cheatlines and restrained design marks appear to be the livery of choice for the majority of owners and operators. However, within the last couple of years, a new, albeit rather discrete, way of visually differentiating business aircraft has emerged, the dedicated corporate aircraft register.

\section{6. 'Make mine a Manx' - new infrastructures of elite aeromobility}

Many of the infrastructures of elite aeromobility, including dedicated business aircraft and business airports, while not always overt, are at least to be expected. A range of business aircraft have been developed to serve the mobility needs of a range of private and commercial customers while dedicated business aviation airports have enable business traffic to avoid the congestion and delays of major commercial airports and passenger terminals. These aircraft and airports are constructed, supported, and maintained by a network of aerospace companies, aircraft brokers, air chartering services, banks, private equity firms, and customer support teams which collectively work to ensure the efficient social and spatial segregation of business aviation. One of the most recent and interesting developments has been the establishment of a new type of infrastructure of elite aeromobility - the dedicated corporate aircraft register - and the extent to which the resulting 'clustering of affluence' is generating new types of segregation within an already elite sector.

On May $1^{\text {st }} 2007$, Europe's first dedicated corporate aircraft register, was established. Based on the Isle of Man, a semi-autonomous island in the Irish Sea, the Manx aircraft register only accepts 'high quality' twin turbine helicopters and fixed wing 
aircraft weighing more than $5700 \mathrm{~kg}$ (smaller aircraft are only accepted if they belong to residents or businesses based on the Isle of Man). Crucially, and unlike other national aircraft registers, aircraft on the Manx register are not permitted to operate public transport flights (Isle of Man Government 2012) rendering it an exclusive register for the aeronautical elite.

According to the Isle of Man Government, the Manx register offers a number of key benefits including the island's stable legal and political environment, its high regulatory standards, its lack of insurance premium tax, and its taxation regime which collectively render it a low-risk investment proposition. The neutral registration prefix ' $\mathrm{M}$-' is also considered an advantage as it not only 'depoliticises' the aircraft (although the decision by some Isle of Man residents to re-register their aircraft on it can be interpreted as being a political statement) but also enables aircraft owners to acquire personalised registration markings in the sequence M-Xxxx. Current examples of these personalised registrations include 'M-AGIC', 'M-IDAS' 'M-YFLY', 'M-YJET', 'MGULF' (on a Gulfstream jet) and 'M-LEAR' (on a Learjet).

Although it only became operational in May 2007, the Manx register has expanded quickly. By the spring of 2010 , it was ranked $15^{\text {th }}$ in the world in terms of the number of bizjets registered on it and by March 2012 there were 343 active registrations. The majority of registrations are for business jets, and most are in the 5-12 seat range. There are also a number of larger aircraft including VIP versions of Airbus and Boeing aircraft, the largest of these currently being an A340, and helicopters. $28 \%$ of registrations are for aircraft that belong to companies or individuals based in the Isle of Man. A further $20 \%$ belong to companies or individuals resident in the British Virgin Islands, and $15 \%, 8 \%$ and $7 \%$ to companies or individuals based in the UK, the Channel Islands and Bermuda respectively. The given address of other Manxregistered aircraft included Gibraltar, The Commonwealth of Dominica, the Cayman Islands, Luxembourg, the Seychelles, Liechtenstein, Switzerland, and Belize.

With the exception of the Channel Islands, Gibraltar, and Liechtenstein, all the other countries in the list have their own national aircraft register. While there is no empirical evidence that explains why these owners chose to re-register their existing aircraft in the Isle of Man, it is not unreasonable to assume that a combination of factors, including considerations of tax, reputation, and status/prestige, may have played a part. At the time of writing, aircraft have been transferred onto the Manx register from over 30 countries, including the USA, Turkey, France, Bermuda, India, Canada, Austria, Mexico, Norway, and Ukraine, while a small number of aircraft formerly on the Manx register have been de-listed and re-registered abroad.

Evidence of such transactions would appear to indicate that there is a global market in business aircraft registrations and the fact that the Manx register is the faster growing corporate aircraft register in the world suggests that the acquisition of a Manx registration is considered an important statement of difference and prestige. 


\section{The challenge of researching elite aeromobilities}

While the Isle of Man aircraft register provides an insight into the types of aircraft that are being flown and the individuals and companies who own them, the fact remains that it is far harder to obtain accurate and up-to-date empirical information on business aviation than it is about commercial aviation. This is no coincidence. Business aviation users choose to fly on private aircraft precisely because they do not want to share a flight with members of the public and they can afford to purchase the discretion and privacy that business aviation offers. The ad-hoc nature of business aviation operations means that flight schedules are not published or publicised in advance (and so details of the origin, departure, and timings of services do not appear on websites or printed timetables) and commercial operators may have signed non-disclosure agreements with their clients which means they are unable or unwilling to reveal information about their services to third parties. As a consequence, these discourses of secrecy, security and client confidentiality render the acquisition of data inherently challenging.

While it is possible to gain some insight into the spatialities of the global business aviation network by using proxy sources, such as national aircraft registers, directories of business aviation companies, and data from air traffic control organisations (where available) such sources often only provide information about individual aircraft or individual flightplans. Even potential new sources of flight information such as flight tracking websites and flight radar apps for smartphones and tablet computers can only offer information about where individual aircraft are at any given point in time. By their very nature such sources are unable to provide information about where individual aircraft are based, how often they are used, who uses them, purposes for which they are used, and the views of people who use and service them. While there is an emerging body of non-academic literature that examines selected aspects of business aviation (for example its economic impact, on which see NEXA 2010), such reports are often produced by external consultants in response to a particular brief or by companies pursuing particular business or political agendas. As such, they rarely consider challenging questions surrounding the longer term social, economic and environmental sustainability of the sector. It is to these themes that the penultimate section of this chapter now turns.

\section{Growing pains: the future of elite aeromobilities}

If, as it has been argued, the business aviation sector is an important barometer of the health of the global economy then the period from 2007 onwards has been a tale of the 'have gots' versus the 'have lots'. One the one hand, the global financial crisis resulted in a dramatic downturn in demand for particular types of business aviation and a rapid contraction of the lower end of the market. Annual deliveries of small and medium sized business jets fell from a high of 1200 units in 2008 to 700 the following year and two manufacturers, Eclipse and Epic, who were engaged in designing a 
new generation of smaller 'very light jets' for owner-operators, ceased trading. As demand for fractional and ad-hoc commercial business aviation operations fell, many providers of business aviation services were forced to dramatically downsize their operation, ground or sell their aircraft, and reduce the size of their workforce.

Globally, the biggest reductions in demand were seen in parts of Asia, the Caribbean, and the Middle East as companies were forced to reduce travel expenditure and 'trade down' to commercial airlines. In the United States and parts of Europe too, there was (albeit largely anecdotal) evidence of shareholders criticising the apparent profligacy of corporate flight at a time of falling interest rates and a volatile stock market. However, while certain sections within the business aviation market were affected by falling demand, demand for very high value products and services was seemingly unaffected. Indeed, growth in the 'VVIP' sector remained strong throughout and helped to offset demand reductions elsewhere. As a consequence, it would appear that the business aviation market is becoming increasingly polarised between the low and high ends of the sector. As the Isle of Man corporate aircraft register shows, new business aviation products and services are emerging that are furthering the internal fragmentation of an already elite sector.

While it appears that growth is returning to certain markets, the vexed question remains as to exactly how much further growth can be expected. If one subscribes to the argument that the market for business aviation in North America and parts of Western Europe is nearing saturation, business aviation operators must look to new and emerging economies in South America and Asia where the potential for uptake may be significant. Considerable growth in business aviation activities has already been recorded in the 'BRIC' economies of Brazil, Russia, India, and China and, given the size of these countries' populations and economic aspirations, it is not unreasonable to assume that this growth will continue for the foreseeable future.

The current scale and likely future growth of the business aviation sector raises challenging questions about the sector's environmental sustainability. Commercial aviation contributes approximately $2-3 \%$ of all anthropogenic carbon dioxide emissions but continued expansion combined with emissions reductions elsewhere has meant that aviation is rapidly becoming one of the fastest growing sources of pollution. Flying on a private aircraft represents a particularly carbon intensive form of mobility that, thanks to existing legislation, enjoys a largely favourable operating environment. Aircraft fuel is not taxed, the taxes and charges that are levied on airline passengers often avoided by private flyers by virtue of the fact that their aircraft are too small to trigger them, and business aircraft flying within Europe will not initially be included in the European Union's Emissions Trading Scheme, a cap and trade system that aims to make the polluter pay for their carbon emissions. This means that it may prove more cost effective (if environmentally damaging) for a company to charter a private jet than pay for a group of employees to travel First or 
Business class on a conventional airline. While various national Governments and legislators have promised to address the environmental externalities of the business aviation sector, they appear wary of imposing additional taxes that may cause wealth-creators, entrepreneurs, and multinational corporations to move overseas to countries where environmental taxes are not imposed. There is a need, therefore, to quantify the environmental impact of business aviation operations at all stages of the service chain, from aircraft manufacture to disposal, and identify how best to improve the sector's environmental performance and help it adjust to an increasingly oilscarce world.

\section{Conclusion}

Business aviation represents a small but high value segment of global air transport industry. It is used by wealthy individuals and corporations as an aid to the conduct of their business and, increasingly, as a lifestyle tool that enables users to engage in particular practices of leisure and consumption. The development of business aviation has described as a reaction against the perceived inadequacies (both spatial, temporal, and social) of conventional passenger aviation, but as the sector has evolved, access to private business aircraft has come to embody notions of personal and professional success. As significantly in the context of this chapter, new discourses of convenience, flexibility, speed, comfort, productivity, and status have collectively (re)invented private flying as a necessity and promoted it as a rational (and often cost-effective) alternative to more conventional forms of aeromobility. This, in turn, has promoted the creation and maintenance of exclusionary spaces of automobile affluence and the existence of a 'hidden' set of supporting infrastructures of operators, airports, maintenance engineers, aerospace companies, specialist finance, and marketing regimes that operate in parallel with, but are distinct from, the more familiar routines of commercial flight.

As the business aviation sector moves into its second century, it is confronted by a range of challenges and opportunities. While many will undoubtedly be overcome through the application of advanced technology, new operating procedures, or updated legislation, all will require a greater understanding of human behaviour and a more nuanced appreciation of the motivations for, and alternatives to, elite aeromobility to be effective. This represents the continued challenged for mobilities research.

\section{References}

Adey, P. (2010) Aerial Life: Spaces, Mobilities, Affects RGS/IBG Book Series Chichester, Wiley-Blackwell. 
Adey, P., Budd, L. C. S., and Hubbard, P. J. (2007) Flying lessons: the social and cultural geographies of global air travel Progress in Human Geography 31(6) pp773791.

Andersen Associates. (2001) Business aviation in today's economy. A shareholder value perspective White Paper Series Number 4 Spring Andersen Associates.

Atkinson, R. (2006) Padding the bunker: Strategies of middle-class disaffiliation and colonisation in the city Urban Studies 43 pp819-832.

Atkinson, R. and Flint, J. (2004) Fortress UK? Gated communities, the spatial revolt of the elites and time-space trajectories of segregation Housing Studies 19 pp875892.

Atkinson, R. and Blandy, S. (2009) A Picture of the Floating World: Grounding the Secessionary Affluence of the Residential Cruise Liner Antipode 41(1) pp92-110.

Beaverstock, J. V., Hubbard, P. J., and Short, J. R. (2004) Getting away with it? Exposing the geographies of the global super rich Geoforum 35 pp401-407.

Bilstein, R. E. (1984) Flight in America. From the Wrights to the Astronauts Baltimore, John Hopkins University Press.

Budd, L. (2011) On being aeromobile: airline passengers and the affective experiences of flight Journal of Transport Geography 19 pp1010-1016.

Budd L and Graham B (2009) Unintended trajectories: liberalization and the geographies of private business flight Journal of Transport Geography 17 (2009) 285-292.

Budd, L. and Hubbard, P. J. (2010) The 'Bizjet set': Business Avaition and the Social Geographies of Private Flight in Beaverstock, J. V., Derudder, B., Faulconbridge, J. and Witlox, F. (Eds.) International Business Travel in the Global Economy Farnham, Ashgate pp85-106.

Bushell, S. (2000) Business Aviation in Jarrett J (Ed.) Modern Air Transport Worldwide Air Transport from 1945 to the Present London, Putnam pp229-242.

Capgemini and Merrill Lynch. (2010) World Wealth Report 2010 Capgemini/Merrill Lynch Retrieved from http://www.it.capgemini.com/m/it/doc/pubbl/wwr_2010.pdf on 03/08/2011.

Cessna. (2008) Printed advertisement for the Cessna Citation X Sourced from Flight International, various dates, 2008. 
Cwerner, S. (2009) Helipads, heliports and urban space Governing the contested infrastructure of helicopter travel in Cwerner, S., Kesselring, S. and Urry, J. (Eds.) Aeromobilities London, Routledge pp225-246.

FlightGlobal. (2011) Business aircraft census 2011 Flight Global 5/10/11 Available online at www.flightglobal.com.

Grob Aerospace. (2008)Printed advertisements for the $s p^{n}$ business jet Retrieved from Flight International, various dates, 2008.

Gulfstream. (2012) Gulfstream corporate homepage www.gulfstream.com Last accessed 26/03/2012.

Isle of Man Government. (2012) Isle of Man Aircraft Registry pages Available at www.gov.im/ded/aircraft Last accessed 26/03/2012.

Marsh, D. (2006) Getting to the point. Business Aviation in Europe. Eurocontrol. Trends in Air Traffic Volume 1. Brussels, Eurocontrol.

National Business Aviation Association. (2004) NBAA Business Aviation Fact Book 2004 Washington DC, NBAA.

National Business Aviation Association. (2010) NBAA Business Aviation Fact Book 2010 Washington DC, NBAA.

NetJets. (2010) Our value proposition Retrieved from

http://www.netjetseurope.com/wps/portal/njecust/netjets/wps/wcm/connect/netjetseu_ en/netjets/welcome-to-netjets/our-value-proposition Accessed 07/12/10.

NEXA. (2010) Business Aviation. An Enterprise Value Perspective Washington DC, NEXA Advisers.

PRC Aviation. (1995) Business Aircraft Operations. Financial Benefits and Intangible Advantages Tuscon, Arizona, PRC Aviation.

PriceWaterhouseCoopers. (2009) The economic impact of business aviation in Europe London, PWc.

Sheehan, J. J. (2003) Business and Corporate Aviation Management. On-demand Air Travel. McGraw-Hill Professional, New York. 